\title{
FIRE SAFETY DESIGN IN BUILDING
}

\author{
Maksum Tanubrata ${ }^{[1]}$
}

\begin{abstract}
The main themes for fire safety planning may be described as follows ; Prevention of outbreak and growth of fire , Fire protection of Building structures, smoke control and escape planning. Fire load in a building can be roughly classified into 3 groups: (a). buildings materials, (b). furniture, and (c). daily goods. Building materials including linings, interior material of walls, ceilings, floors, partition walls, etc, and daily goods such as books, clothes, and so on.
\end{abstract}

Keywords : Fire protection, Safety, Buildings materials, Furniture.

\begin{abstract}
ABSTRAK
Untuk perencanaan bangunan gedung kita harus memperhatikan pencegahan dari bahaya kebakaran, cara menyelamatkan diri dari gedung bila terjadi kebakaran Beban api untuk bangunan secara garis besar dapat dibagi menjadi : (a). bahan bangunan, (b). mebel, dan (c). perlengkapan lainnya. Material bangunan termasuk lantai, dinding, atap, dinding partisi beserta isinya seperti buku, kertas dan lain sebagainya.
\end{abstract}

Kata kunci : Pecegahan kebakaran, Keamanan, Bahan bangunan.

\section{INTRODUCTION}

In general, through the word, fire safety of building is ensured by taking measures of the fire codes or standards usually require the safety performance for a certain hours in each building members in buildings.

However, keeping or following codes is usually very difficult not only for existing buildings, but for new ones in every country when new items for fire safety are introduce in the revised regulations. Measures for fire safety in buildings may be developed in accordance with more research work and experiences.

Development of fire safety measures are not same as that of electronics or mechanics, etc. The former is always based on the preferable ways or ideal ways for human lives. That is, fire safety may be based on the balanced between cost for safety planning and the lost when buildings get fire.

Then, we should always consider the principle of fire safety from the point of daily life and architecture. The main themes for fire safety planning may be described as follows :

1. Prevention of outbreak and growth of fire.

2. Fire protection of Building structures. 
3. Smoke control and escape planning.

The problems are how can we get free from these items. It's easy to say, but difficult to conduct actually. Let's think together about the items in detail.

\section{GROWTH OF FIRE}

\subsection{Start and spread of a fire}

A fire starts by various cause. Fire is a rapid reaction of combustible materials with oxygen, producing heat and light. For combustion, the mixing ratio between the combustible gas released from combustible materials and an oxidizing agent (air, etc) must be in a certain range. The minimum ratio of the concentration of the combustible gas is called the lowest limit of combustion, and the maximum, the upper limit of combustion. Many materials ignite or catch fire at elevated temperatures as listed in Table 1

Table 1. Ignitation-Temperatures of various materials

\begin{tabular}{|l|c|c|}
\hline \multicolumn{1}{|c|}{ Material } & $\begin{array}{c}\text { Ignitation } \\
\text { Temperatures } \\
{ }^{0} \mathrm{C}\end{array}$ & $\begin{array}{c}\text { Auto-ignition } \\
\text { Temperatures } \\
{ }^{0} \mathrm{C}\end{array}$ \\
\hline Wool & 200 & - \\
Paper & 230 & 230 \\
Cotton & $230-266$ & 254 \\
Polymethylmethacrylate & $280-300$ & $450-462$ \\
Rigid polyurethane foam & 310 & 416 \\
Polyethylene & 341 & 349 \\
Polystyrene & $345-360$ & $486-496$ \\
Polister (glass fibre filled) & $346-399$ & $483-488$ \\
Polyvinylchoride & 391 & 454 \\
Polyamide (Nylon) & 421 & 424 \\
Phenolic resins (glass fibre filled) & $520-540$ & $571-580$ \\
\hline
\end{tabular}

The heat released by the combustion of materials is fed back to the material, to promote the thermal decomposition of the material and the release of combustible gases. Oxigen is needed to continue the combustion.

When the buildings materials burn, they give different calorific values as shown in Table 2.

The fire growth / spread characteristics such as ease of ignitation of fire, spread velocity and emission of heat, smoke and hazardous gases etc, are determined by many factors such as the geometric conditions of the room, openings, initial fire source, distance 
between the fire source and combustible materials, type and volume of materials and situation or arrangement in the room, etc.

Fire rapidly spreads upward by buoyancy and convection, and then spread laterally along ceiling when a fire occurs in a confined space. Combustions generates gases as well as heat and smoke. Hot gases will fill the entire room. The temperatures in the plume can be as 650 to $950{ }^{0} \mathrm{C}$. Unignited parts in the room will be preheated by the convection from hot gases and irradiation from the hot area. Combustible interior materials will have a significant influence on fire growth and spread in the room.

While a fire grows, it effects to surrounding materials which will be degraded, melted, burnt and collapsed etc. Examples of effect at elevated temperatures are shown in Table 3.

Table 2. Calorific values of building materials

\begin{tabular}{|c|l|c|}
\hline No & \multicolumn{1}{|c|}{ Material } & $\begin{array}{c}\text { Calorific value } \\
(\mathrm{MJ} / \mathrm{Kg})\end{array}$ \\
\hline 1 & Asbestos slate (specific gravity 1.8) & 0 \\
2 & Rock wool sound absorbing board (starch 7\%) & 0.84 \\
3 & Rock wool sound absorbing board (starch 12\%) & 2.09 \\
4 & Plaster board (without paper) & 0.42 \\
5 & Plaster board (with paper) & 6.28 \\
6 & Pulp cement board (pulp 8\%) & 1.47 \\
7 & Pulp cement board (pulp 15\%) & 2.09 \\
8 & Excelsior board (excelsior 45\%. Specific gravity & $3.14-5.36$ \\
& (0.70-0.85) & \\
9 & Japanese cedar board (specific gravity 0.45) & 18.92 \\
10 & Plywood (specific gravity 0.50) & 18.84 \\
11 & Particle board (specific gravity 0.55) & 16.74 \\
12 & Hard fiberboard (specific gravity 0.85) & 20.09 \\
13 & Soft fiberboard (specific gravity 0.40) & 14.65 \\
14 & Polyvinyl Chloride tile (vinyl chloride 10\%) & 15.07 \\
15 & Polyvinyl Chloride tile (vinyl chloride 30\%) & 19.38 \\
16 & Asphalt tile & 17.33 \\
17 & Buber tile & 15.91 \\
18 & Linoleum & 21.35 \\
\hline
\end{tabular}

Table 3. Effect of temperature on selected materials

\begin{tabular}{|c|l|l|c|}
\hline Substance & \multicolumn{1}{|c|}{ Typical examples } & \multicolumn{1}{|c|}{ Conditions } & $\begin{array}{c}\text { Approximate } \\
\text { temperature }\end{array}$ \\
\hline Polystyrene & $\begin{array}{l}\text { Thin wall food containers } \\
\text { Foam, light shades, handles, } \\
\text { curtain hooks, radio casings }\end{array}$ & $\begin{array}{l}\text { Collapse } \\
\text { Softens } \\
\text { Melts and flows }\end{array}$ & $\begin{array}{c}120{ }^{\circ} \mathrm{C} \\
120-140 \\
250\end{array}$ \\
\hline
\end{tabular}




\begin{tabular}{|c|c|c|c|}
\hline \multicolumn{4}{|c|}{ Table 3. (continued) } \\
\hline Polystylene & $\begin{array}{l}\text { Bags, Films } \\
\text { Bottles, buckets }\end{array}$ & $\begin{array}{l}\text { Shriwels } \\
\text { Softens and melts }\end{array}$ & $\begin{array}{l}120 \\
150\end{array}$ \\
\hline $\begin{array}{l}\text { Polymethyl } \\
\text { methacrylate }\end{array}$ & Handles, covers, "glazing” & $\begin{array}{l}\text { Softens } \\
\text { Bubbles }\end{array}$ & $\begin{array}{c}130-200 \\
250\end{array}$ \\
\hline PVC & Cables & $\begin{array}{l}\text { Degrades } \\
\text { Fumes } \\
\text { Browns } \\
\text { Charing } \\
\end{array}$ & $\begin{array}{c}100 \\
150 \\
200 \\
400-500 \\
\end{array}$ \\
\hline Cellulose & Wood, paper, cotton & Darkens & $200-300$ \\
\hline Solder & Plumbing joints & Melts & 250 \\
\hline Lead & $\begin{array}{l}\text { Plumbing } \\
\text { Sanitary installations, Toys }\end{array}$ & $\begin{array}{l}\text { Melts, sharp edges } \\
\text { Rounded } \\
\text { Drop formation }\end{array}$ & $200-350$ \\
\hline $\begin{array}{l}\text { Alumunium } \\
\text { And } \\
\text { Alloys }\end{array}$ & $\begin{array}{l}\text { Fixture, casings } \\
\text { Brackets, small mech } \\
\text { Parts }\end{array}$ & $\begin{array}{l}\text { Softens } \\
\text { Melts } \\
\text { Drop formation }\end{array}$ & $\begin{array}{r}400 \\
650\end{array}$ \\
\hline Glass & Glazing, bottles & $\begin{array}{l}\text { Softens, rounded } \\
\text { Flowing easily } \\
\text { viscous }\end{array}$ & $\begin{array}{l}500-600 \\
850\end{array}$ \\
\hline Silver & Jewellery, spoons & $\begin{array}{l}\text { Melts } \\
\text { Drop formation }\end{array}$ & 950 \\
\hline Brass & $\begin{array}{l}\text { Locks, taps } \\
\text { Doorhandles, lapes }\end{array}$ & $\begin{array}{l}\text { Melts (particularly } \\
\text { At edges) } \\
\text { Drop formation }\end{array}$ & $900-1000$ \\
\hline Copper & $\begin{array}{l}\text { Wiring, Cables } \\
\text { Ornaments }\end{array}$ & Melts & $1000-1100$ \\
\hline Cast iron & $\begin{array}{l}\text { Radiators } \\
\text { Pipes }\end{array}$ & $\begin{array}{l}\text { Melts } \\
\text { Drop formation }\end{array}$ & $1100-1200$ \\
\hline Zink & $\begin{array}{l}\text { Sanitary installation } \\
\text { Sutter, Down pipes }\end{array}$ & Drop formation & 400 \\
\hline Bronce & $\begin{array}{l}\text { Windows, fittings, door bells, } \\
\text { Ornamentation }\end{array}$ & $\begin{array}{l}\text { Rounds } \\
\text { Drop formation }\end{array}$ & 1000 \\
\hline Paints & - & $\begin{array}{l}\text { Deteriorates } \\
\text { damages }\end{array}$ & $\begin{array}{l}100 \\
250\end{array}$ \\
\hline Wood & - & ignits & 200 \\
\hline
\end{tabular}

\subsection{Flashover}

One of most peculiar phenomena occurs in the early stage of fire.. It is called "flashover" which is the sudden growth of a fire involving the whole room with a big flame.

A thipical growth of a room fire is drawn by the temperatures rise which is shown in fig.1. At the stage of $\mathrm{O}$ to $\mathrm{A}$ in the figure, a small fire grows gradually, and its behavior changes depending on the conditions of fire source, materials, openings and volume of the 
room, etc. The stage of B to C after the flashover is a developed stage. The behavior of the fire depends upon the sizes of windows, the heat insulation inside the room and volume of fire etc.

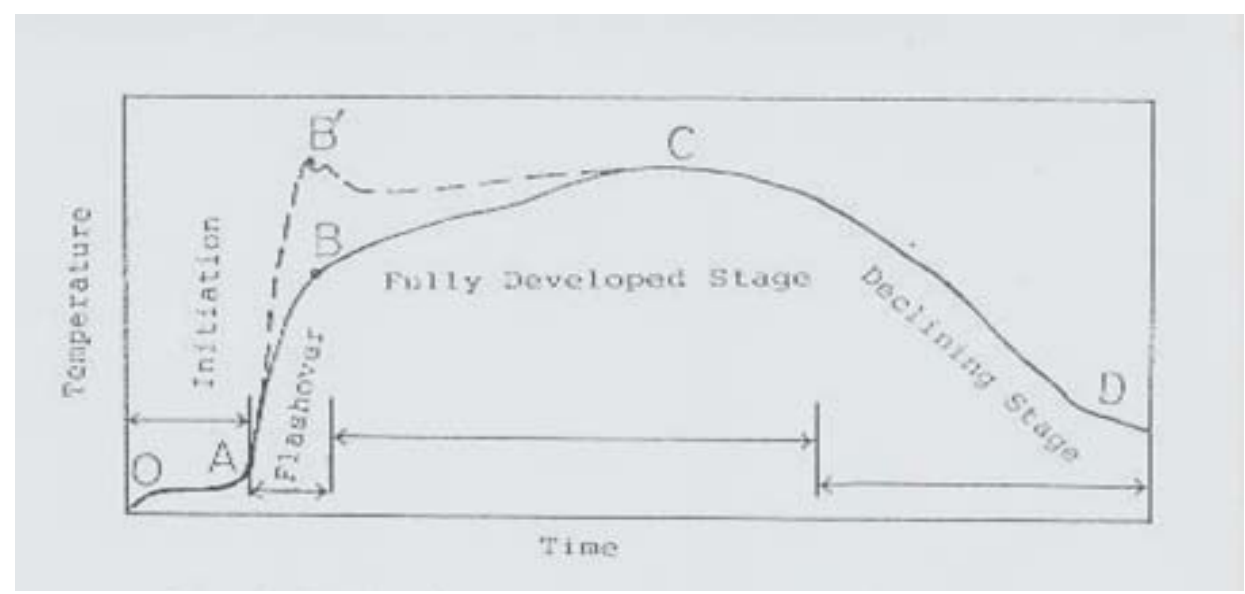

Figure 1. Typical pattern of stages of fire growth

When flashover occurs, heat, smoke and gases are vigorously released. Therefore, the duration from the start of a fire to flashover has an important role.

A phenomenon like intermittent explosive combustion can be seen as a special case of flashover, depending on the relationship between then kinds and volume of combustion gas, etc.

For the prevention of outbreak of a fire, "How can we do?". The answer should be left to the participants today. For the prevention of growth of it in a room, minimum use of combustible materials for walls, ceiling, floors, furniture and daily goods will be required. For the stop of fire from a room to another, compartmentation of building space must be taken.

A better compartmentation in each building member such as wall, beam, column, floor etc, must consists of fire resisting.

\section{FIRE LOAD}

Before concideration of compartmentation, we must consider the phenomena of fire.

The main factors governing the duration of he fire are the volume of combustible materials contained in the building and the openings as mentioned above. For fire protection design of a building structure, it is essential to know the volume of combustible materials in a designed building, for predication of a burning rate. 
Fire load in a building can be roughly classified into 3 groups:
a. buildings materials,
b. furniture
c. daily goods.

Building materials including linings, interior material of walls, ceilings, floors, partition walls, etc, and daily goods such as books, clothes, and so on.

These combustible materials have different calorific values to release heat in combustion.

The heat release from the different materials in a room during a fire are often expressed by the "relevant fire load" which means the equivalent heat value of that of a similar amount of wood.

Therefore, for a design of fire-resisting building, the equivalent fire load is often used for simplication.

Mean volume of fire load in various types of building in Japan is shown in Table 4. These data were obtained by actually weighed in many buildings.

Concerned to each building, there figure do not accurately meet, but there will be useful for engineering treatment

Fire load at the Hotel Bali Beach is shown in Table 4 as an example.

Table 4. Fire load at the Hotel Bali Beach

\begin{tabular}{|c|c|}
\hline Application of building & Ordinary range $(\mathrm{Kg} / \mathrm{m} 2)$ \\
\hline Hotel $\quad$ Bedroom & 7- 11 \\
\hline Meeting room & $2-6$ \\
\hline Office & $30-80$ \\
\hline (bad room) & $3-5$ \\
\hline Library & $62-93$ \\
\hline Dweling (apartement house) & $35-60$ \\
\hline Classroom & $30-45$ \\
\hline Warehouse & $640-1020$ \\
\hline $\begin{array}{l}\text { Shop } \\
\text { (excuding bookstore and other stores } \\
\text { containing much combustible materials) }\end{array}$ & $100-200$ \\
\hline
\end{tabular}


Table 5. Fire load in Building in Japan

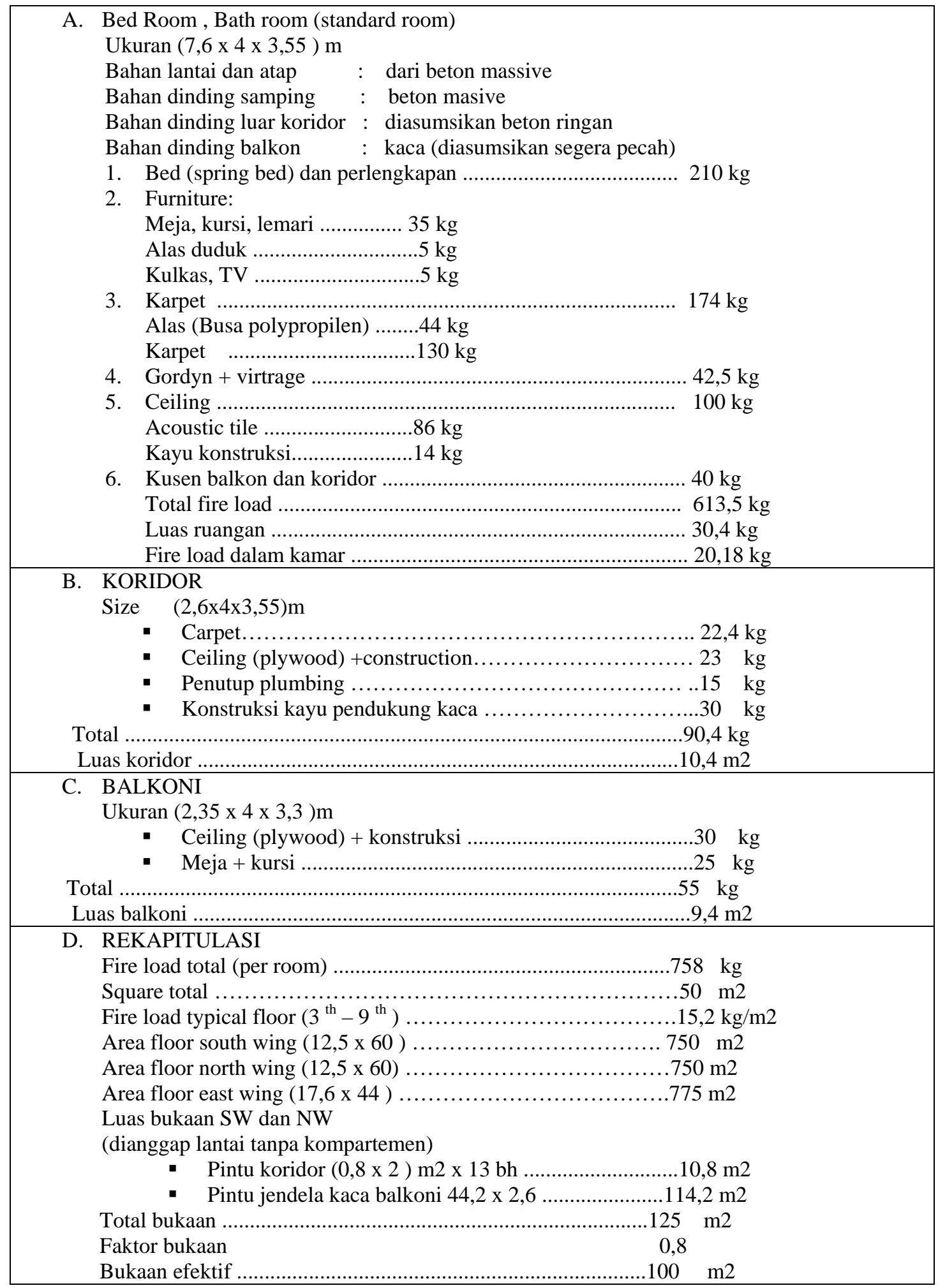




\section{TEMPERATURES AND DURATION OF A ROOM FIRE}

In a fire- resisting building, the combustion rate is controlled by area of the openings.

The relationship between the burning rate $\mathbf{R}$ at the stage of a fully developed fire in a room is expressed as follows. The burning rate is mainly related with the area and the height of the opening.

$$
\mathrm{R}=\mathrm{k} \times \mathrm{A} \sqrt{ } \mathrm{H}
$$

Where : $\quad \mathrm{R}$ : Burning Rate ( $\mathrm{Kg} / \mathrm{min})$

$\mathrm{K}$ : Coefficient $(5.5-6.0)$

A : Area of the opening $(\mathrm{m} 2)$

$\mathrm{H}$ : Height of the opening (m)

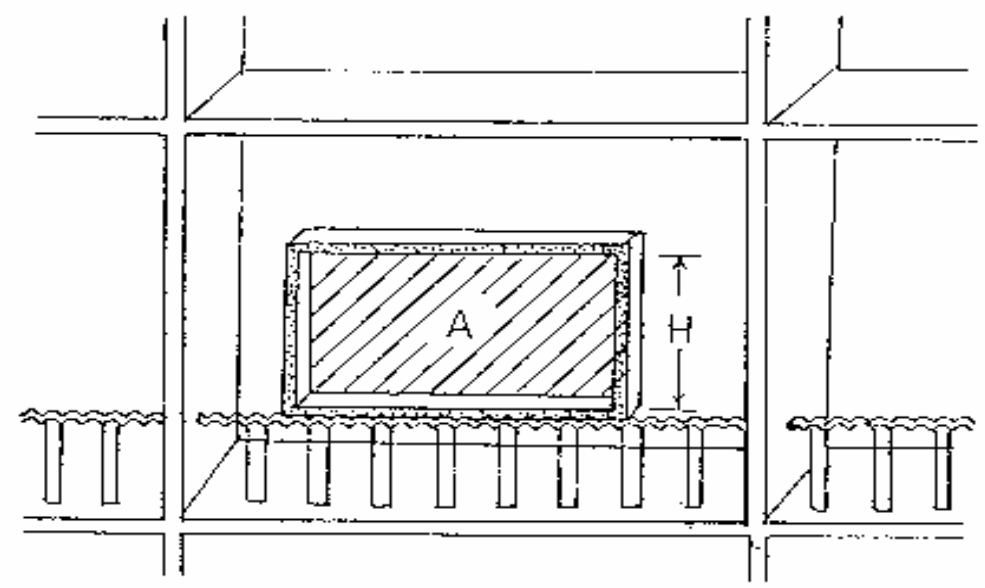

Figure 2. Opening of a compartment

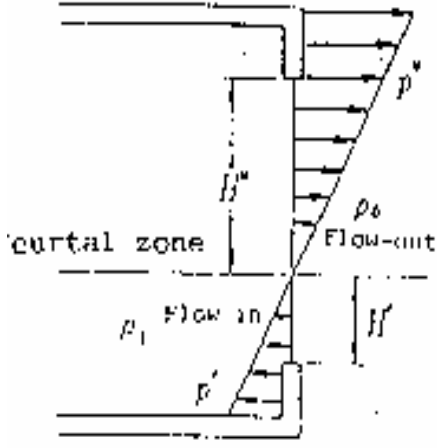

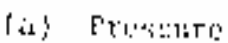

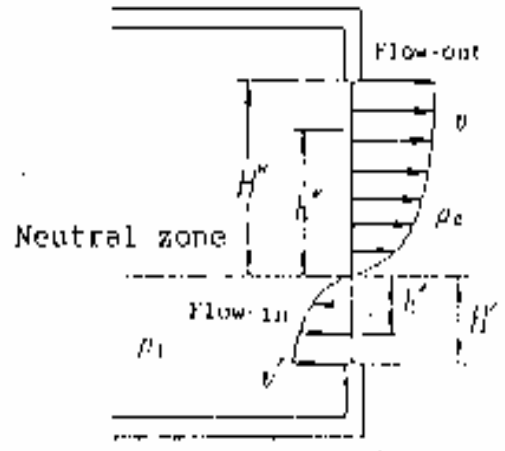

(t) velocity

Figure 3. Air flow at the opening in fire 
If temperatures anywhere in a room are assumed to be uniform, a neutral zone of flow-in and out of air appears as shown in Fig.3 with linear pressure distribution which is proportional to the height. The air velocity pattern is expressed in Fig.3 (b).

\section{PHONEMENA OF STRUCTURES}

As regards reinforced concrete structures, their members generally lose strength depending on the depth of protecting insulation of mortal.

Concrete members gradually lose their outer layer in fire and the steel inside becomes exposed to fire. Fig. 4 show the typical phenomena at the depth of the concrete when heated under the standard fire exposure.

The phenomena, i.e., popping of the concrete, significantly affects the fire resistance of the material. It is also more likely to occur in pre-stressed and pre-cast concrete structural members.

According to the results of fire-resistance test, the following conditions are found to be significant for members:

1. heat source

2. the early stages of fire retardancy

3. water content of loaded force

4. application of loaded force

5. the corner section of beams and columns, etc.

Fig.4 and Fig.5 show the affect of temperature on the compressive strength of concrete.

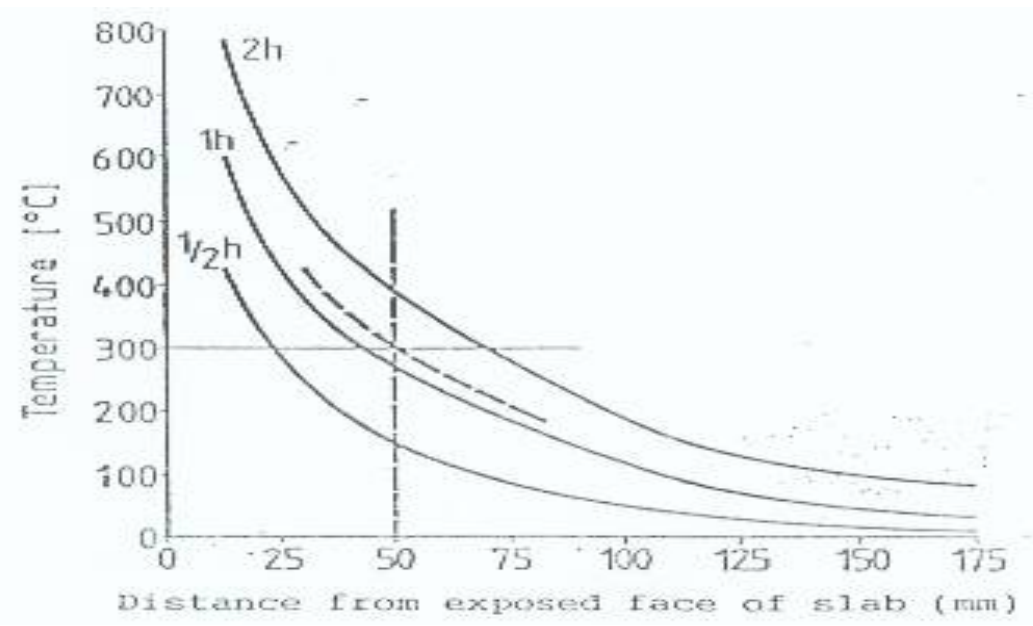

Figure 4. Temperature distribution in slab exposed to a standard fire 


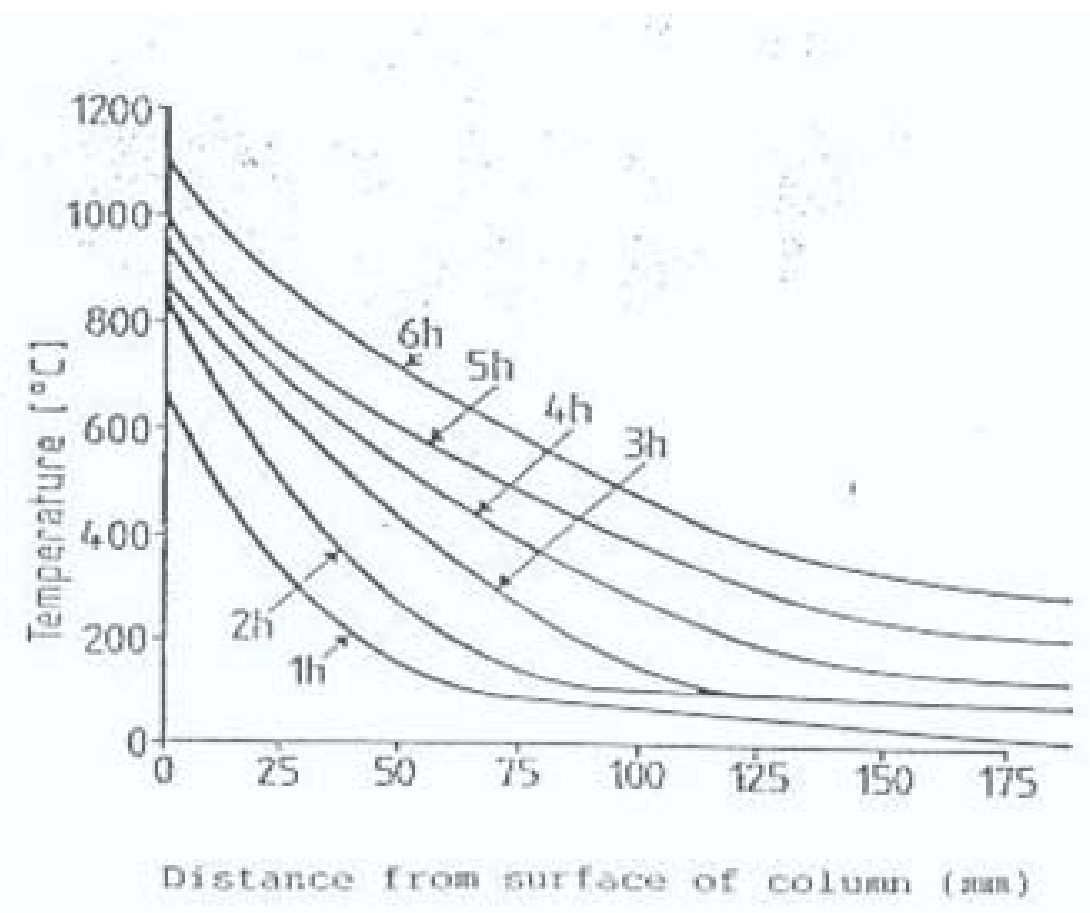

Figure 5. Temperature distribution in $350 \mathrm{~mm}$ columns exposed to a standard fire

\section{FIRE PROTECTION OF BUILDING STRUCTURE}

\subsection{Fire-Resisting Design}

For the protection of buildings from structural damage during fire, structural members are required to be protected by means of fire protection methods.

Fire-resistance requirements are made depending on the type, design and size of building.

The regulatory control for fire protection is required to be concerned with safeguarding the occupants in the building where a fire may occur. To minimize the risk to adjacent buildings and avoiding conflagrations, consideration must be given to the plan, layout and construction of the building for controlling the growth of a fire.

The fire performance is usually rated into four classes which are 3 hours, 2 hours, 1 hours and half an hour endurance.

Fire doors or fire protection assemblies are to be applied to the openings on the exterior wall of a fire-resistance construction where there may be imminent danger of spread of a fire. 


\subsection{Compartmentation Planning}

A fire which start in a space a building spread to a junction spaced, finality involving the whole building, due to the hot current from the burnings rooms through corridors, staircases, opening of windows, doors, etc.

Therefore, in large-scale and / or high rise buildings, it is important to stop the fire in a restricted enclosure in a certain time after initiation.

This is called fire compartmentation, and is protected by fire resistant walls, floors, columns and beams.

For the design of the fire-resistance building, fundamental consideration is given to the type, design and size of buildings as shown in Fig.6 and detailed components are shown in Fig.7.

The principle for fire-resistance design is as follows:

1. Scale of fire is to be estimated in each fire zone. The main structural components are designed to endure for the estimated fire load and duration in each fire zone.

2. Fire safety for the whole building is to be estimated with the product of safety coefficient based on the data from each fire zone, depending on the use, scale and structure etc.

3. Main structural components are to be resistant for more than estimated fire duration.

In many years ago, there was no idea or no regulation for compartmentation of space in building in most countries.

Japan introduced the idea into fire regulation in there twenty years. The Hotel Bali Beach was constructed by a Japanese constructor in 1965. Then, there was no regulation for compartmentation.

That's why fire spread very easily through the whole building in not longer time. Fortunately no facilities are there during Fire on Wednesday January 20, 1993. Smoke control and escape planning are also very important measures for fire safety planning. There subjects are left to Mr.I. Hagiwara.

We must consider the fire safety from the point of architecture prior to consulting fire fighting after catching fires. 


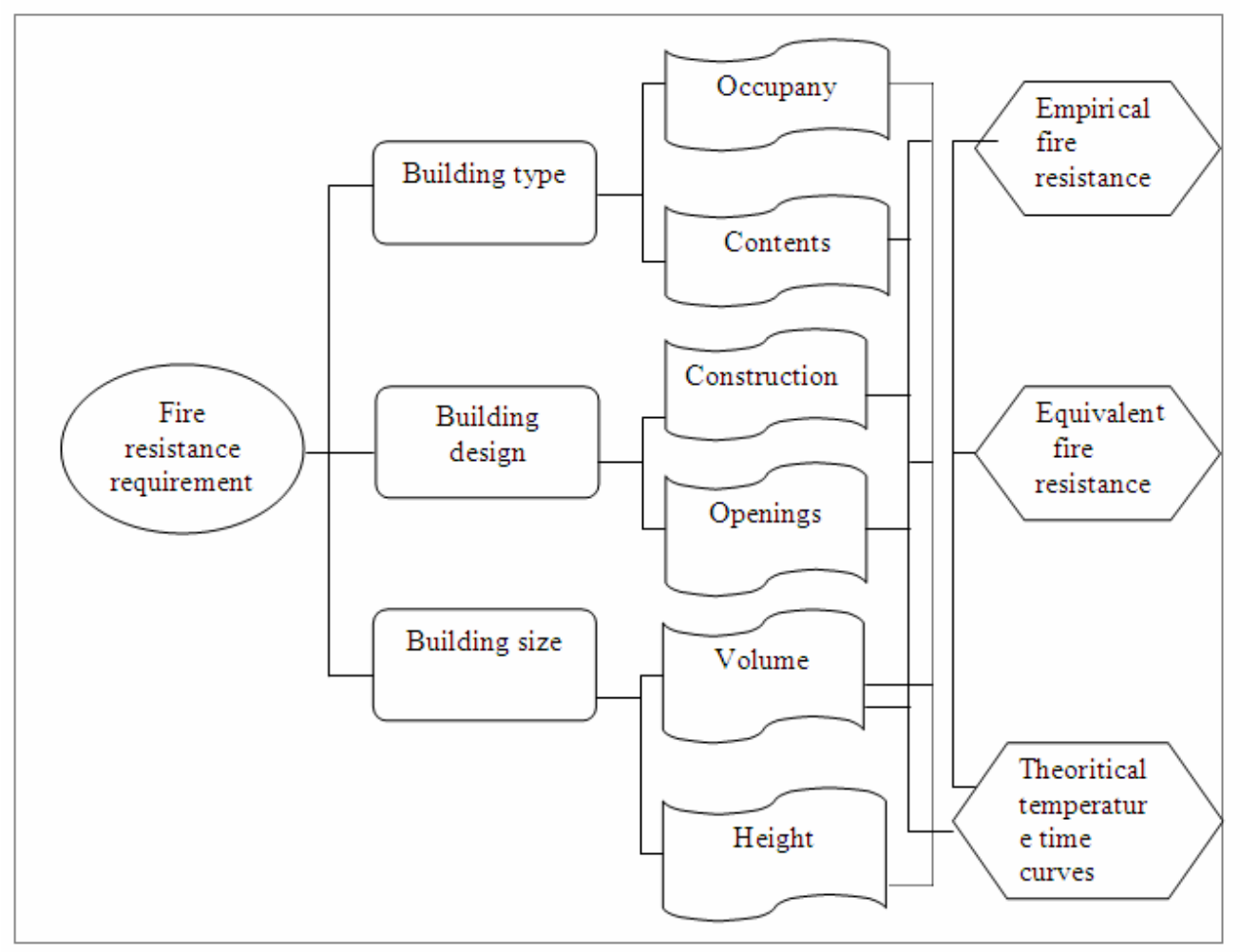

Figure 6. Method of defining fire resistance need

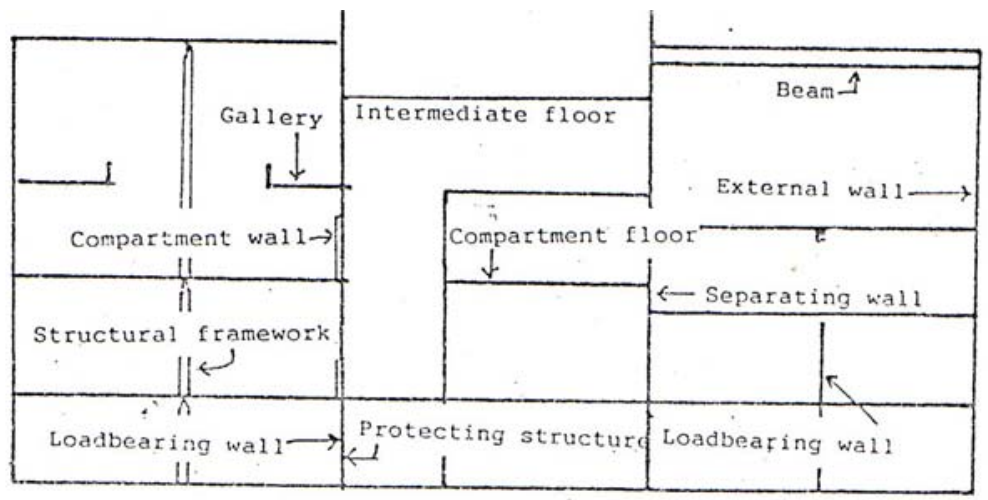

,

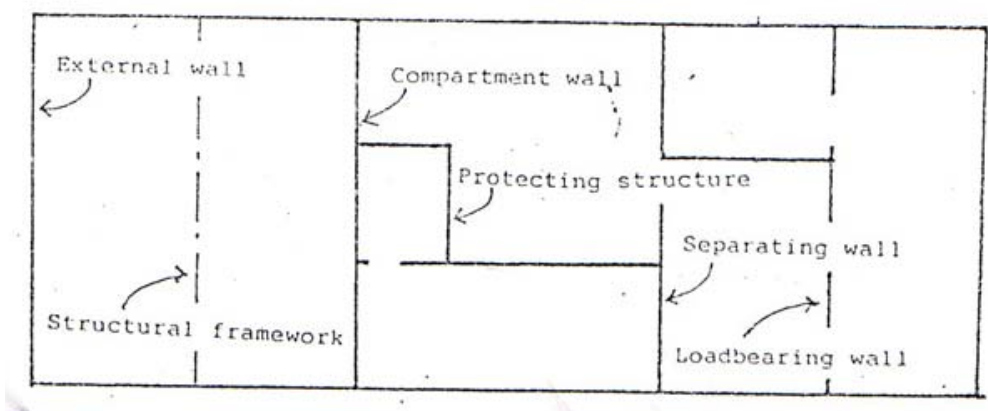

Figure 7. Various components of a building to which

fire resistance requirements apply 


\section{SUMMARY AND CONCLUSION}

The principle for fire-resistance design is as follows:

1. Scale of fire is to be estimated in each fire zone. The main structural components are designed to endure for the estimated fire load and duration in each fire zone.

2. Fire safety for the whole building is to be estimated with the product of safety coefficient based on the data from each fire zone, depending on the use, scale and structure etc.

3. Main structural components are to be resistant for more than estimated fire duration

4. The fire performance is usually rated into four classes which are 3 hours, 2 hours, 1 hours and half an hour endurance.

5. Fire doors or fire protection assemblies are to be applied to the openings on the exterior wall of a fire-resistance construction where there may be imminent danger of spread of a fire.

\section{REFERENCES}

1. Malhotra , H.L (1992), Design of fire Resisting Structures, $3^{S T}$ ed, surrey University Presc, London.

2. Egan, M David, (1998), Concepts in Building Fire Safety, John Wiley and Sons Canada.

3. Suprapto (Jakarta, 21 Desember 1993), “Keamanan Bangunan terhadap kebakaran, suatu tinjauan dari Identifikasi Bahaya, Konsep aman kebakaran dan evaluasi keandalan”Lokakarya dan evaluasi system.

[1] Maksum Tanubrata, Lecturer, Department of Civil Engineering, Maranatha Christian University, Bandung. E-mail : maksum.tanubrata@eng.maranatha.edu. 